\title{
Conceptualization of Notions and Formation of Quality Indicators of Educational Services
}

\author{
${ }^{1}$ Lev I. Fishman, ${ }^{2}$ Liliana A. Sosunova, ${ }^{* 3}$ Sergey V. Noskov, ${ }^{4}$ Valentina V. Agafonova, ${ }^{5}$ Anna N. Sivaks \\ ${ }^{1}$ Doctor of Economics, Doctor of Pedagogical Sciences, Professor of Samara State University of Social Sciences \\ and Education, Samara, Russia. \\ ${ }^{2, * 3,4}$ Doctor of Economics, Professor of Samara State University of Economics, Samara, Russia, 443090, Sovetkoi \\ Armii Str., 141. \\ ${ }^{5}$ Candidate of Economic Sciences, Associate Professor of Samara State University of Economics, Samara, Russia, \\ 443090, Sovetkoi Armii Str., 141. \\ E-mail:l_fishman@mail.ru,kafedra-kl@yandex.ru,"noskov50@yandex.ru,wagaf@mail.ru,anna.sivaks@yandex.ru
}

Received: 29 ${ }^{\text {th }}$ June 2018, Accepted: $10^{\text {th }}$ July 2018, Published: 31 ${ }^{\text {st }}$ August 2018

\begin{abstract}
The relevance of the research topic is caused by insufficiently high quality and competitiveness of educational services in the Russian Federation. One of the reasons for this is imperfection of methodological approaches to formation of indicators of qualitative results of providing educational services. Issue statement: the quality of educational services is understood in different ways both by researchers and by various participants of the services market. This creates problems in formation of quality indicators of educational services and decision-making by all concerned parties. The research purposes consist in conceptualization of notions, which are related to the quality of educational services, and development of a system of indicators of their evaluation, reflecting interests of services users, their producers, and management bodies. The research methods include methods of scientific abstraction and concretization of generic concepts of quality, summaries, groupings and ranking of quality indicators of educational services, their clustering. The methods of mathematical statistics and theory of probability are also used. The results and key conclusions: conceptualization is carried out and the difference in the notions, related to the quality of educational services, is revealed. The system of quality indicators of services of higher professional education is formed, their ranking and clustering is carried out. A gap between the consumer quality of educational services and the quality of services that are used in practice has been established.
\end{abstract}

Keywords: Higher Education, Quality of Educational Services, Clustering, Competitiveness, Conceptualization of Notions, Quality Indicators, Ranking.

\section{Highlights:}

1. Conceptualization is carried out, the difference of notions "quality of educational service", "quality of production of educational service", "consumer quality", "competitiveness of educational service" is revealed, the specificity of educational services is defined.

2. The system is created from 20 quality indicators of services of higher professional education, revealed in the process of conducting group discussions (focused interviews).

3. Ranking of the quality indicators of services of higher professional education is carried out on the basis of the analysis of results, obtained in the course of conducting focus groups.

4. 4 clusters, characterizing various importance for students of certain groups of the quality indicators of educational services, are emphasized.

5. The gap between the consumer quality of educational services and the quality of services that are used in practice has been established.

\section{Introduction}

\section{Establishing a context}

The concepts "quality of educational service", "quality of production of educational service", "consumer quality", "competitiveness of educational service" are used nowadays both by researchers and consumers and also by education authorities of various levels in absolutely different meanings, with different connotations. This creates obvious problems not only in daily communication of people or in communication of experts, but also in the course of managerial decision-making, for example, in control of the quality indicators, competitiveness and monitoring of services. In application of these concepts both in theory and practice of decision- 
making, needs of direct consumers of educational services remain incomprehensible, not articulated and unaccounted.

\section{Brief Literature Review}

The research is based on ideas about specificity of services in general (Gronroos, 1982; McDougall \& Levesque, 2000) [1-2] and social services, in particular (Stiglitz, 2000; Ivanov, 2011; Ivanov \& Fishman, 2013) [3-5], about quality of products, including educational services and quality management (Feigenbaum, 2004; Harrington, 1987; Mittal \& Lassar, 1998; Walton, 1991; Pankrukhin, 2003) [610], about competitiveness (Rubin, 2010; Fatkhutdinov, 2008; Fatkhutdinov, 2009; Gelvanovskiy, Rozhkov \& Skryabina, 2009) [11-14]. It is also based on our own research in the field of quality and competitiveness of educational services (Fishman, 2009; Fishman \& Matveeva, 2015; Fishman $\&$ Tsybina, 2015) [15-17]. Studies on ensuring the quality of education (Blanco-Ramírez \& Berger, 2014) [18], the integrated education model (Sultan, 2012) [19], determinants of transfer of knowledge and competences of education are also presented in the scientific literature (Rusu, 2015) [20]. Besides, the research is based on the analysis of standards of higher professional education and a certain understanding of professional competences (Golub, Fishman \& Fishman, 2013; Golub, Fishman \& Fishman, 2010) [21, 22].

\section{Establishing a Research Gap}

In works of the above-mentioned authors, the applied concepts in the context of the research subject are characterized by unjustified variety and unequal meaning. This raises difficulties in their practical use, besides there are no studies on perception of the quality of services of higher professional education by consumers.

\section{Stating the Purpose}

The purpose of the article consists in conceptualization of the notions "quality of educational service", "quality of production of educational service", "consumer quality", "competitiveness of educational service" and also experimental assessment of differences between inquiries of students for consumer quality of educational services and those quality indicators, which are used in practice by education authorities.

Achievement of the stated research purpose required solution of the following objectives:

- discussion of the generic notions "quality of educational service", "quality of production of educational service", "consumer quality", "competitiveness of educational service";

- determination of the specificity of educational services;

- realization of experiment on establishment of correspondence between indicators of the consumer quality of educational services and the quality indicators of services, established by education authorities.

\section{Material and Methods}

The leading research method is the method of scientific abstraction, methods of concretization of generic notions of quality, specificity of educational services. Performance of the experiment required to use methods of formation of focus groups of respondents, summaries, groupings and ranking of the quality indicators of educational services, their clustering. Also methods of mathematical statistics and theory of probability are used, in particular laws of distribution of respondent responses, average values, mean-square deviations and correlation coefficients.

\section{Results}

\section{Theoretical Research Results:}

1. Conceptualization of the notions, related to the quality of education is carried out. The concepts "quality of educational services", "quality of production of educational services" and "consumer quality of educational services" are emphasized.

2 . The specificity of educational services is defined in the aspect of their quality.

The content of the specificity of educational services is showed in Figure 1.

3. Conceptualization of the notion "competitiveness of educational service" is carried out. Competitiveness of educational services is ability of services and educational programs to compete with other product units, in connection with their choice by clients or refusal of consumption of this service in market conditions. In this case it is necessary to consider consumers of services, other subjects making decision on the choice, which up to the level of professional education are parents of clients.

\section{Empirical Research Results:}

The investigational study on correspondence of inquiries of undergraduate students of Samara State University of Social Sciences and Education for the consumer quality of educational services to the quality indicators, used in practice, is conducted.

1. The system is created from 20 quality indicators of 
services of higher professional education, revealed in the process of conducting group discussions (focused interviews). In the course of formation of focus groups more than 700 students - future holders of a bachelor's degree- were interviewed. The system of the quality indicators of services of higher professional education is presented in Table 1.

\begin{tabular}{|c|l|}
\hline$№$ & \multicolumn{1}{|c|}{ Quality Indicators of Services } \\
\hline 1. & Practical orientation of training \\
\hline 2. & Assistance in provision of employment on the part of the higher education institution \\
\hline 3. & Skill of lecturers to get on well with students and benevolence of the dean's office \\
\hline 4. & A distinct structure of imposed requirements and transparency of assessment of students \\
\hline 5. & Location of an academic building (a possibility to get to the place of study by public transport) \\
\hline 6. & Prestige of the higher education institution \\
\hline 7. & Existence of a dormitory near academic building \\
\hline 8. & $\begin{array}{l}\text { Good material and technical resources (modern renovation, comfortable furniture, availability of technical } \\
\text { teaching aids) }\end{array}$ \\
\hline 9. & $\begin{array}{l}\text { Well-developed infrastructure (existence of a good canteen, sports grounds, parking, campus, availability } \\
\text { of a library, a possibility to use Wi-Fi) }\end{array}$ \\
\hline 10. & Skill of lecturers to give training material in an understandable way \\
\hline 11. & Absence of grafts in the training process \\
\hline 12. & Convenience of a timetable and absence of failures in it \\
\hline 13. & Existence of an opportunity for students to study alongside employment \\
\hline 14. & An opportunity for students to realize one's potential in various directions (in creative work or public life) \\
\hline 15. & Provision of students with places of apprenticeship \\
\hline 16. & Academic degrees and titles of lecturers \\
\hline 17. & Active scientific activities of lecturers \\
\hline 18. & Existence of programs and methodological materials on courses taught \\
\hline 19. & A possibility for students to engage in scientific activity \\
\hline 20. & Organization of internships and foreign education \\
\hline
\end{tabular}

Tab. 1: The System of the Quality Indicators of Services of Higher Professional Education 


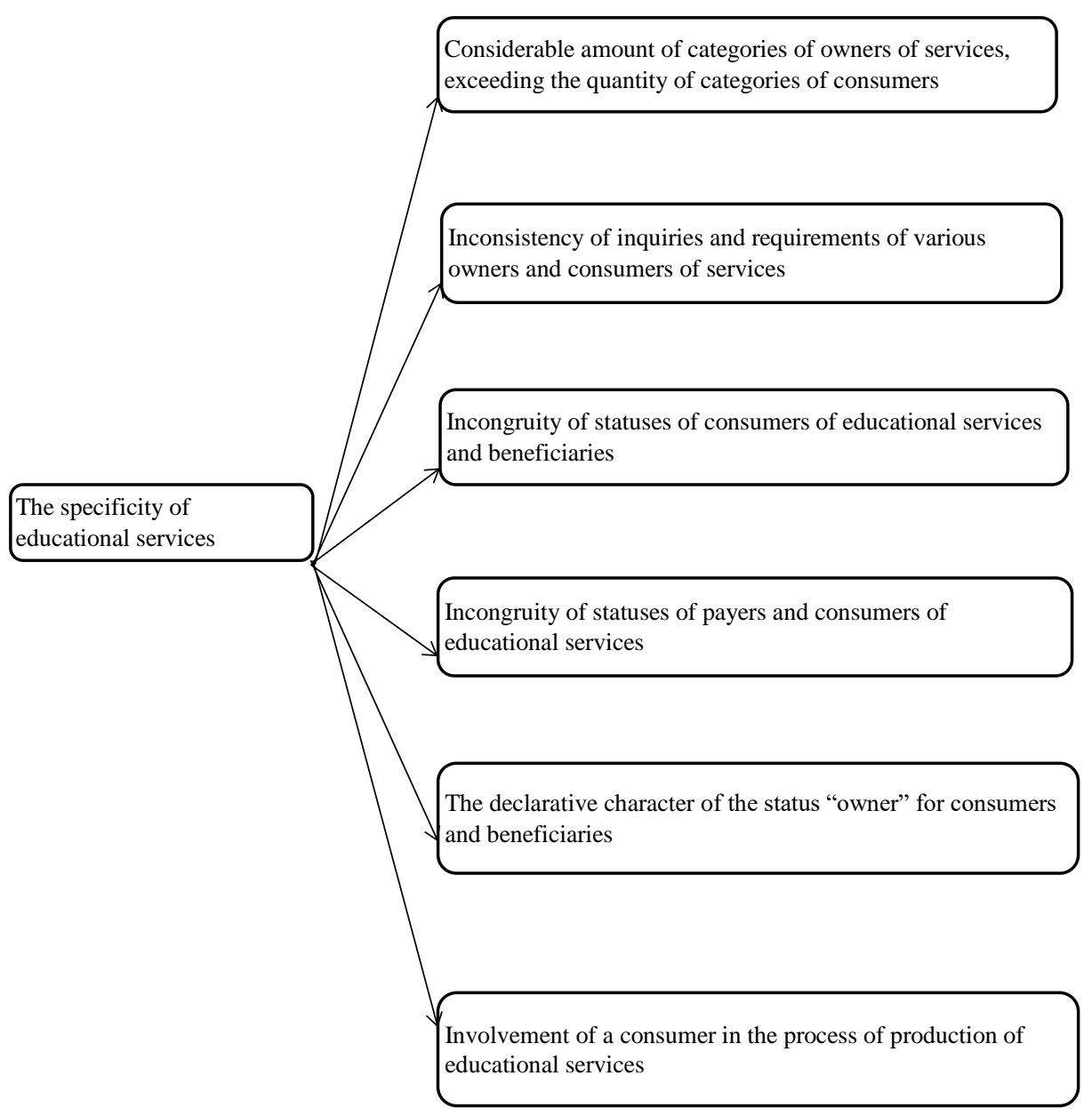

Fig. 1: The Content of the Specificity of Educational Services.

Source: It is developed by the Authors.

2. Ranking of the quality indicators of services of basis of the analysis of results, obtained in the course higher professional education is carried out on the of conducting focus groups is reflected in Table 2.

\begin{tabular}{|c|l|c|c|}
\hline$№$ & Quality indicators of services & $\begin{array}{l}\text { Average score of } \\
\text { evaluation of } \\
\text { significance }\end{array}$ & $\begin{array}{l}\text { Ranking by average } \\
\text { score }\end{array}$ \\
\hline 1. & Practical orientation of training & $\mathbf{8 , 7 3}$ & 5 \\
\hline 2. & $\begin{array}{l}\text { Assistance in provision of employment on the part of the } \\
\text { higher education institution }\end{array}$ & $\mathbf{8 , 3 2}$ & 2 \\
\hline 3. & $\begin{array}{l}\text { Skill of lecturers to get on well with students and benevolence } \\
\text { of the dean's office }\end{array}$ & $\mathbf{6 , 3 6}$ & \\
\hline 4. & $\begin{array}{l}\text { A distinct structure of imposed requirements and } \\
\text { transparency of assessment of students }\end{array}$ & $\mathbf{8 , 4 1}$ & \\
\hline 5. & $\begin{array}{l}\text { Location of an academic building (a possibility to get to the } \\
\text { place of study by public transport) }\end{array}$ & $\mathbf{1 0 , 8 9}$ & 11 \\
\hline 6. & Prestige of the higher education institution & $\mathbf{1 1 , 0 3}$ & 13 \\
\hline
\end{tabular}




\begin{tabular}{|c|c|c|c|}
\hline 7. & Existence of a dormitory near academic building & 13,69 & 19 \\
\hline 8. & $\begin{array}{l}\text { Good material and technical resources (modern renovation, } \\
\text { comfortable furniture, availability of technical teaching aids) }\end{array}$ & 10,18 & 7 \\
\hline 9. & $\begin{array}{l}\text { Well-developed infrastructure (existence of a good canteen, } \\
\text { sports grounds, parking, campus, availability of a library, a } \\
\text { possibility to use Wi-Fi) }\end{array}$ & 10,55 & 9 \\
\hline 10. & $\begin{array}{llllll}\text { Skill of lecturers to give training material in an } \\
\text { understandable way }\end{array}$ & 5,43 & 1 \\
\hline 11. & Absence of grafts in the training process & 12,15 & 16 \\
\hline 12. & Convenience of a timetable and absence of failures in it & 9,20 & 6 \\
\hline 13. & $\begin{array}{l}\text { Existence of an opportunity for students to study alongside } \\
\text { employment }\end{array}$ & 10,57 & 10 \\
\hline 14. & $\begin{array}{l}\text { An opportunity for students to realize one's potential in } \\
\text { various directions (in creative work or public life) }\end{array}$ & 11,26 & 14 \\
\hline 15. & Provision of students with places of apprenticeship & 10,27 & 8 \\
\hline 16. & Academic degrees and titles of lecturers & 13,14 & 18 \\
\hline 17. & Active scientific activities of lecturers & 13,89 & 20 \\
\hline 18. & $\begin{array}{l}\text { Existence of programs and methodological materials on } \\
\text { courses taught }\end{array}$ & 12,00 & 15 \\
\hline 19. & A possibility for students to engage in scientific activity & 12,93 & 17 \\
\hline 20. & Organization of internships and foreign education & 11,01 & 12 \\
\hline
\end{tabular}

Tab. 2: Ranking of the Quality Indicators of Educational Services by Respondents Source: It is developed by the Authors

3. The hierarchical cluster analysis of indicators of educational services is carried out. The preliminary analysis of the ranging results of average scores of the quality indicators by students allowed distinguishing five groups according to the Sturges' formula. The matrix of Euclidean distances is developed for 5 clusters. It is presented in Table 3.

\begin{tabular}{|c|c|c|c|c|c|}
\hline № & $1,2,4,12$ & 3 & $5,6,20,14,8,15,9,13,11,18$ & $7,17,16,19$ & 10 \\
\hline $1,2,4,12$ & 0 & 1.96 & 0.98 & 3.73 & 2.89 \\
\hline 3 & 1.96 & 0 & 3.82 & 6.57 & 0.93 \\
\hline $5,6,20,14,8,15,9,13,11,18$ & 0.98 & 3.82 & 0 & 0.78 & 4.75 \\
\hline $7,17,16,19$ & 3.73 & 6.57 & 0.78 & 0 & 7.5 \\
\hline 10 & 2.89 & 0.93 & 4.75 & 7.5 & 0 \\
\hline
\end{tabular}

Tab. 3: The Matrix of Euclidean Distances

Source: It is developed by the Authors.

The quality indicators of educational services of 5 clusters are presented in tables 4, 5, 6, 7, 8 .

\begin{tabular}{|l|l|}
\hline № & The quality indicators of services \\
\hline
\end{tabular} 


\begin{tabular}{|l|l|}
\hline 1. & Practical orientation of training \\
\hline 2. & Assistance in provision of employment on the part of the higher education institution \\
\hline 4. & A distinct structure of imposed requirements and transparency of assessment of students \\
\hline 12. & Convenience of a timetable and absence of failures in it \\
\hline
\end{tabular}

Tab. 4: The Quality Indicators of Educational Services of the $1^{\text {st }}$ cluster

Source: It is developed by the Authors.

\begin{tabular}{|l|l|}
\hline$№$ & The quality indicators of services \\
\hline 3. & Skill of lecturers to get on well with students and benevolence of the dean’s office \\
\hline
\end{tabular}

Tab. 5: The Quality Indicators of Educational Services of the $2^{\text {nd }}$ cluster

Source: It is developed by the Authors.

\begin{tabular}{|l|l|}
\hline № & The quality indicators of services \\
\hline 5. & Location of an academic building (a possibility to get to the place of study by public transport) \\
\hline 6. & Prestige of the higher education institution \\
\hline 20. & Organization of internships and foreign education \\
\hline 14. & $\begin{array}{l}\text { An opportunity for students to realize one's potential in various directions (in creative work or public } \\
\text { life) }\end{array}$ \\
\hline 8. & $\begin{array}{l}\text { Good material and technical resources (modern renovation, comfortable furniture, availability of } \\
\text { technical teaching aids) }\end{array}$ \\
\hline 15. & Provision of students with places of apprenticeship \\
\hline 9. & $\begin{array}{l}\text { Well-developed infrastructure (existence of a good canteen, sports grounds, parking, campus, } \\
\text { availability of a library, a possibility to use Wi-Fi) }\end{array}$ \\
\hline 13. & Existence of an opportunity for students to study alongside employment \\
\hline 11. & Absence of grafts in the training process \\
\hline 18. & Existence of programs and methodological materials on courses taught \\
\hline
\end{tabular}

Tab. 6: The Quality Indicators of Educational Services of the $3^{\text {rd }}$ cluster

Source: It is developed by the Authors.

\begin{tabular}{|l|l|}
\hline № & The quality indicators of services \\
\hline 7. & Existence of a dormitory near academic building \\
\hline 17. & Active scientific activities of lecturers \\
\hline 16. & Academic degrees and titles of lecturers \\
\hline 19. & A possibility for students to engage in scientific activity \\
\hline
\end{tabular}

Tab. 7: The Quality Indicators of Educational Services of the $4^{\text {th }}$ cluster Source: It is developed by the Authors.

\begin{tabular}{|l|l|}
\hline № & The quality indicators of services \\
\hline 10. & Skill of lecturers to give training material in an understandable way \\
\hline
\end{tabular}

Tab. 8: The Quality Indicators of Educational Services of the $5^{\text {th }}$ cluster

Source: It is developed by the Authors.

The cluster field of the quality indicators of educational services is showed in Figure 2. 
Helix Vol. 8(5): 3651- 3660

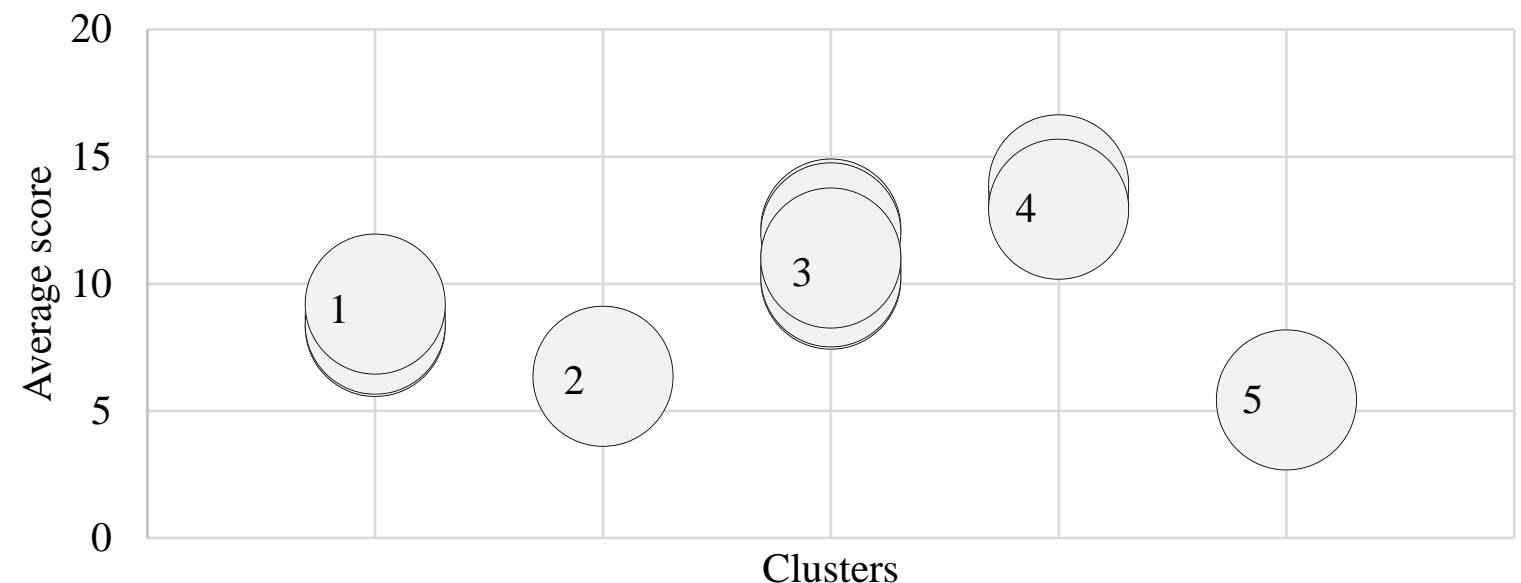

Fig. 2: The Cluster Field of Educational Services.

Source: It is developed by the Authors.

4. The discrepancy between a set of indicators of the consumer quality and the quality indicators of services that are used in practice, including implementation of procedures of the state control over the quality of education, is established. 


\section{Discussions}

The main research hypothesis is assumption about incomplete compliance of the quality indicators of educational services, implemented by education authorities, and the indicators of their quality, reflecting requirements of consumers of services. The research conducted in this field has theoretical and practical results.

\section{Discussion of the Theoretical Research Results:}

It is expedient to apply the notion "quality of educational service" to assessment of relevant properties of this service by various subjects of the external environment of educational organizations for determination of the degree of their compliance to inquiries of consumers and various beneficiaries. It is fundamentally important not to confuse this notion with "quality of production of educational service" certain indicators of the production process and the resources providing this process.

The notion "consumer quality" of educational service does not always include the results of rendering of service; it is consigned to important characteristics of the process of rendering of service and is determined by increase in value of direct effects, connected with the fact of consumption of the service of this producer. From the position of other beneficiaries of educational services, including parents of consumers and other close persons and also the state, the notion "quality of educational services" should include, firstly, educational results, secondly, some characteristics of the process of rendering of services, for example, connected with safety of students, satisfaction of inquiries of considerable groups of students and their representatives and, thirdly, actually long term effects. The specificity of educational services include:

- The declarative character of the status "owner" for consumers and beneficiaries of the most massive educational services. The specified incongruity of the statuses of a consumer and a payer in case of absolute majority of educational services is resulted in limitation of a possibility of consumers to be owners that is to be considered as such by producers of educational services. It means inattention of producers to consumer inquiries for the nomenclature and consumer properties of educational services. According to the requirements of educational standards of professional education, employers should be owners. In the normative documents, regulating education, and in the established culture great many subjects of the external environment are considered as subjects, which formulate requirements to educational services. These are consumers of educational services, their parents, future employers, various other communities, founders and, finally, the state;

- Involvement of a consumer in the process of production of educational services.

The integral specificity of educational services is the fact that for their receiving a consumer should be involved in its production process. Involvement of a consumer into the production process of service is characteristic of a number of services, designed to satisfy the needs of high level. It refers, for example, to some services of the cultural sphere: museum, theatrical and another. A certain level of training of a client is necessary for consumption of some of these services. The majority of educational services involve obtainment of educational results, which are "external" for a client as he should acquire knowledge, skills, methods of activity, predetermined by educational standards and programs. Assignment of external educational results is impossible without implementation of certain actions. These actions, as well as assigned results, differ a little at various clients; that is caused by their unequal psychophysical characteristics, experience, and the initial level of training. Besides, acquisition of educational results requires a purposeful activity of a consumer of this service, which purposes are set in many respects from the outside.

In the context of its correct use, the notion "competitiveness of educational service" has limited scope of application. It is expedient to use it as a characteristic of the ability of an educational product to be chosen. Therefore it makes sense to apply the term "competitiveness" only in the aspect of behavior of consumers, conscious that competitiveness of an educational service is determined by ideas of consumers and other persons, helping consumers to make a choice or making a choice for them, about educational results; about important for consumers and for persons helping them to make a choice, characteristics of the process of rendering of services; about the closest and removed effects of service consumption, ideas about the price and expenses, connected with receiving a service.

From the position of such beneficiary as the state, the consumer quality of educational services can be significantly at variance with competitiveness of these services. The conducted conceptualization of the notions allows explaining the lack of correlation between competitiveness of producers of educational services and their quality. The mechanisms of government funding of educational services, which are used in practice, promote increase in this divergence.

\section{Discussion of Empirical Research Results:}

The purpose of carrying out an empirical research was formation of the system of the quality indicators of services of higher professional education. The research method was the method of discussion in focus groups of parameters (important for students) of the services rendered by higher education institution. By the results of the discussion, the preliminary list of the quality indicators was created. Unification of responses, which are close in meaning, and exception of rare ones - allowed creating the system from 20 indicators.

At the second research stage, a questionnaire was developed from the quality indicators of educational services, chosen by students. Students were offered to give a quantitative assessment on a scale of 1 to 20 to the quality level of each indicator in decreasing order 
of values. Further mathematical and statistical processing of the received results was carried out. In particular, laws of distribution of responses of 700 students emerged as random variables. Laws of distribution were established visually according to the form of the distribution density curve. The majority of students' scores corresponded to the normal law of distribution.

Coherence of students' estimates was checked on the basis of variation coefficients (relative deviations from average scores on each quality indicator of educational services). The majority of estimates were coherent as the variation coefficients did not exceed $20 \%$.

The preliminary analysis of the ranging results of the average scores of the quality indicators by students allowed distinguishing five groups according to the Sturges' formula:

$n=1+3.322 \cdot \lg N, \quad n=1+3.322 \cdot \lg 20=5.3$,

where $n$ - the quantity of clusters in the sample;

$N$ - the amount of the analyzed quality indicators of educational services.

Consequently, from formal positions the average estimates of the quality of educational services by respondents can be presented in the form of five groups of indicators (clusters). Emphasizing of clusters was carried out according to the table 2, the method of "the nearest neighbor" (an agglomerative hierarchical classification algorithm) was used.

The algorithm of the method is based on determination of the Euclidean distance between the average scores of certain qualitative characteristics of educational services by students. This algorithm enabled to reduce consistently the quantity of clusters to the predetermined number ( 5 clusters), basing on the matrixes of distances in scores of estimates.

In this connection, in the first cluster (in sequence, but not in order of importance) there were the quality indicators of educational services $(1,2,4,12)$, relating to the educational process and external effects of education.

The second cluster includes only one indicator (3) -the skill of lecturers to get on well with students and benevolence of the dean's office. In order of importance, basing on the average score of assessment of significance, this indicator is inferior only to the skill of lecturers to give training material in an understandable way (10). The indicator characterizes not so much the consumer quality of education as the condition of the internal environment of the university. The third cluster includes the quality indicators relating to the university's infrastructure, its material and technical resources, prestige and organization of interaction with the external environment and also self-realization $(5,6,20,14,8,15,9,13,14,18)$.

The least significant quality indicators of educational services according to the students' opinion, however the most important from the point of view of education authorities $(7,17,16,19)$, were included in the fourth cluster.

The fifth cluster forms the only one and the most important indicator of the consumer quality of educational services, which fulfills the education purpose - acquisition of knowledge, skills or formation of professional competences (10).

The results of the cluster analysis are presented in the graphic model of the cluster field of the quality indicators of services of higher professional education. The analysis has shown that consumers practically do not consider the quality indicators of production of service in a specific educational organization or the education system. It means that a number of the quality parameters of production of educational services are definitely important production conditions.

The results of the conducted research can be useful for higher education authorities of different levels for formation of the quality indicators of the services reflecting requirements of students and beneficiaries. The field of future studies can be formation of offers on the structure of the quality indicators of educational services reflecting their consumer quality for modification of standards of higher professional education.

\section{Conclusion}

1. Conceptualization of the notions "quality of educational service", "quality of production of educational service", "consumer quality", "competitiveness of educational service" is carried out.

2. The specificity of educational services is revealed.

3. Ranking of the quality indicators of educational services is conducted.

4. The hierarchical cluster analysis of the quality indicators of educational services is carried out.

5. The gap between the consumer quality of educational services in perception of students and the quality indicators of services that are used in practice is established.

\section{References}

[1] Gronroos, Ch. (1982). Strategic management and marketing on the service sector. Helsingfors. Publisher: Swedish School of Economics and Business Administration, $222 \mathrm{p}$.

[2] McDougall, G.H.G. \& Levesque, T. (2000). Customer Satisfaction with services: putting perceived value into equation. Journal of Services Marketing. Vol. 14 (5), pp. 392-410.

[3] Stiglitz, J.E. (2000). Economics of the public sector. New York: W.W. Norton \& Company, 823 p.

[4] Ivanov, M.Yu. (2011). Teoreticheskie osnovy monitoringa effektivnosti organov upravleniya 
territorialno-otraslevymi kompleksami sotsialnykh uslug: monogr. Samara: Izdatel'stvo "PGSGA", 164 p. (In Russian).

[5] Ivanov, M.Yu., \& Fishman, L.I. (2013). Metodologiya proektirovaniya organizatsionno-finansovykh mekhanizmov byudzhetnogo finansirovaniya v otrasli kultury: monograf. Samara: Izdatel'stvo "PGSGA", 140 p. (In Russian).

[6] Feigenbaum, A.V. (2004). Total Quality Control. New York: McGraw-Hill, 4th edition, $896 \mathrm{p}$.

[7] Harrington, H.J. (1987). The Improvement Process: How America's Leading Companies Improve Quality. New York: McGraw-Hill, 239 p.

[8] Mittal, B. \& Lassar, W.M. (1998). Why do customers switch? The dynamics of satisfaction versus loyalty. Journal of Services Marketing, Vol. 12 (3), pp. 177 194.

[9] Walton, M. (1991). Deming Management at Work. New York: Perigee Books, 249 p

[10] Pankrukhin, A.P. (2003). Marketing obrazovatelnykh uslug: metodologiya, teoriya i praktika. Retrieved from: http://www.marketing.spb.ru/lib-special/branch/mou/. Moscow. Data publikatsii 21.01.03., 159 p. (In Russian).

[11]Rubin, Yu. B. (2010). Diskussionnye voprosy sovremennoy teorii konkurentsii. Sovremennaya konkurentsiya, Vol. 3 (21), pp. 38-67.

[12] Fatkhutdinov, R.A. (2008). Upravlenie konkurentosposobnostyu organizatsii. Moscow: Market DS, 432 p. (In Russian).

[13] Fatkhutdinov, R.A. (2009). Urovni i obyekty konkurentosposobnosti. Sovremennaya konkurentsiya, Vol. 4 (16), pp. 123-143 (In Russian).

[14] Gelvanovskiy, M.I., Rozhkov, K.L. \& Skryabina, N.I. (2009). Konkurentosposobnost natsionalnoy ekonomiki: problemy statisticheskogo soprovozhdeniya. Poisk metodologicheskoy adekvatnosti. Moscow: IITs "Statistika Rossii", 383 p. (In Russian).

[15] Fishman, L.I. (2009). Metodologiya i mekhanizmy povysheniya kachestva obrazovatelnykh uslug na osnove delegirovaniya obratnykh svyazey. Samara: Samarskiy nauchn. Tsentr "RAN", 180 p. (In Russian).

[16] Fishman, L.I. \& Matveeva, N.N. (2015). Protsessnyy podkhod $\mathrm{v}$ upravlenii kachestvom obrazovatelnogo protsessa $\mathrm{v}$ vuze kak sredstvo povysheniya kachestva obrazovatelnykh rezultatov. Samara: "PGSGA", 160 p. (In Russian).

[17] Fishman, L.I. \& Tsybina O.Yu. (2015). Vospriyatie studentami kachestva obrazovatelnykh uslug v vuze: rezultaty empiricheskogo issledovaniya. Vestnik of Samara State University of Economics, Vol. 12 (134), pp. 47-52 (In Russian).

[18] Blanco-Ramírez, G. \& Berger, J.B. (2014). Rankings, accreditation, and the international quest for quality. Quality Assurance in Education, 22(1), pp. 88-114.
[19] Sultan, Y.W. (2012). Ho Service quality in a higher education context: An integrated model. Asia Pacific Journal of Marketing and Logistics, Vol. 24 (5), pp. 755-784.

[20]Rusu, C. (2015). Determinants of knowledge and competences transfer in education. Review of Management and Economic Engineering, Vol.14, No. 1(55), Todesco Publishing Hous, Cluj-Napoca, pp. 1528.

[21] Golub, G.B., Fishman, I.S. \& Fishman, L.I. (2013). Obshchie kompetentsii vypusknikov vysshey shkoly: chto standart trebuet ot vuza. Voprosy obrazovaniya, Vol.1, pp. 156-173 (In Russian).

[22] Golub, G.B., Fishman, I.S. \& Fishman, L.I. (2010). Standarty tretyego pokoleniya: chemu uchit i chto proveryat na vykhode. Voprosy obrazovaniya, Vol. 3, pp. 102-114 (In Russian). 